\author{
Mendel Eleonóra PhD \\ emendelova@ukf.sk
}

egyetemi adjunktus (Nyitrai Konstantin Filozófus Egyetem Pedagógiai Kar)

\title{
A korszerü család transzformációs trendjei a modern társadalomban
}

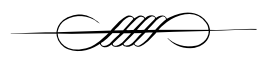

\section{- Transformation of Contemporary Family in Modern Society -}

Aвstract The paper describes family as a social institution, which passes through some changes caused by societal, political, economic changes. In the first part of the paper there are analysed aspects of changes in family life (changes in perceiving the value of marriage, in demographic processes, in structure etc.), and there is certain direction to the different pattern and different arrangement of a life in contemporary families. In the second part of the paper we also analyses global reasons for introduced changes (changes in societal values and social norms, labour migration, changed sexual morality, individualisation and the effort to keep individual freedom).

KEYWORDS family, family changes, marriage, demographic processes, structure of family, family relations, changes in societal values and social norms, labour migration, individualism

DOI 10.14232/belv.2016.4.5 https://doi.org/10.14232/belv.2016.4.5

Cikkre való hivatkozás / How to cite this article: Mendel Eleonóra (2016): A korszerü család transzformációs trendjei a modern társadalomban. Belvedere Meridionale 28. évf. 4. sz. 71-82.pp

ISSN 1419-0222 (print) ISSN 2064-5929 (online, pdf)

(Creative Commons) Nevezd meg! - Így add tovább! 4.0 (CC BY-SA 4.0)

(Creative Commons) Attribution-ShareAlike 4.0 International (CC BY-SA 4.0)

www.belvedere-meridionale.hu 


\section{Bevezetés}

A család szerepe a társadalomban nélkülözhetetlenül fontos, mert egyrészt menedéket nyújt tagjainak az elszenvedett sérelmekért, és intim közösség lévén a család tagjainak érzelmileg is stabilitást biztosít. Az emberek többségének a sikeres házasság és a kiegyensúlyozott család az elégedettség és boldogság alapja, életútjuk középpontja és fontos szociális, de elsősorban érzelmi és erkölcsi háttér. Számos kutatás igazolja, hogy a kiegyensúlyozott családi élet a testi és lelki egészség, s egyben a szubjektívan átélt boldogság tényezője. Jelentős szociális intézmény, amely az egészség után a boldogság és megelégedettség legfontosabb alapjaként jelenik meg.

A család történelmileg meghatározott szociális csoport, amely a társadalom legkisebb önálló egysége. E szerkezet biztosítja a társadalom emberutánpótlását, mennyiségileg és minőségileg egyaránt. Mint elsődleges csoport, közvetítő egység az egyén és a társadalom között, mert az egyénben az adott társadalom viszonylatai jelennek meg, illetve a társadalom viszonyai az egyén magatartásában realizálódnak. A családra minden társadalomban szükség van, mert az ember nemcsak társas lény, hanem individuum is egyben, akinek szüksége van magánéletre, és ezt a család biztosítja elsősorban.

A család viszonylag zárt egység, nagy kohéziójú csoport, amely sajátosan szüri, töri a külső hatásokat. Mint a társadalom legkisebb, önálló közössége sokrétűen összeszövődik az egész társadalom fejlődésével (JANCSÁK 2013, SomLAi 2013). A társadalmi fejlődés a családok életében alapvető változásokat eredményez, müködési mechanizmusokban, struktúrájukban, kapcsolatokban egyaránt. A társadalom gazdasági nehézségei, a társadalmi értékek és normák általános elbizonytalanodása stb. eredményezik a családok életében már évtizedek óta megfigyelhető jelentős átalakulást (JANCSÁK 2013, SoMLAI 2013, BECK 2016).

A rendszerváltást követően a volt kommunista országokban felgyorsultak a változások. Томка (2009) szerint egyenesen egy új fejlődési szakaszról beszélhetünk. A tanulmány a család szerkezetében és működésében jelenleg tapasztalható fejlődési trendeket foglalja össze az első részben, a másodikban pedig elemzi a változásokat kiváltó globális társadalmi indokokat. A rendszerváltás utáni időszakban megfigyelt transzformációs folyamatokra fókuszál Szlovákia, ill. a középeurópai posztkommunista országok térségében.

\section{A korszerü család átalakulása}

A háztartások és a családok nagysága és szerkezete viszonylag keveset változott az ipari forradalom alatt és a megelőző néhány évszázadban Nyugat-Európában. Vitathatatlanul jelentős változások következtek be azonban a 20. század folyamán (ToмkA 2000. 46.). Hasonlóan nyilatkoznak Plaňava (2000) és MožNÝ (2006). PlaňAva (2000) szerint a történelmi visszatekintés azt igazolja, hogy az első világháború végétől a család lényegesen változni kezdett és folyamatosan alakult át. Nem marginálisan, hanem alapvető jegyeiben. A változások ugyan az utolsó két évtizedben figyelhetők meg, de az impulzusai a 19. és a 20. század határáig vezethetők vissza, felgyorsulva a második világháború utáni időszakban. Mély gyökerekkel rendelkező változásokról van szó, melyek a 20. század második felében mutatkoztak meg (MožNÝ 2006). A családi életben bekövetkezett változások a következő aspektusokban nyilvánultak meg: 


\section{Változások a házasság értékében és értelmében}

A hagyományos család hozzájárult a társadalom stabilitásához azzal, hogy a házastárs kiválasztása a szülők kezében volt. Ök választották ki a jövendőbeli partnert tekintettel a gazdasági és kulturális habitusra, figyelembe véve a nemesi családok, ill. gazdasági települések, iparos mühelyek lehetséges összekötését. Manapság a házasságba való belépés egyértelmű motivációja a szerelem és a kölcsönös szimpátia, a szülök egyetértése csupán formális jellegü.

A nők keresőtevékenységének általánossá válásával a házasságkötés női motivációja alapvetően megváltozott. A múltban, a férjhezmenetel volt a nők számára jövőjük biztosításának legfőbb eszköze. Ma az önálló kereset mellett a nők nagy része számára nem jelent anyagi nyereséget a házasságkötés, hiszen meg tudnak állni a maguk lábán. Ez feltétlenül szerepet játszik a házasságkötés nélküli együttélések terjedésében, abban, hogy a nők nem érzik hátrányosnak a maguk számára, ha nem biztosítják jogi szerződéssel, az anyakönyvezető előtt megkötött házassággal azt, hogy férjük szükség esetén eltartásukra kötelezhető. Hasonlóan szerepet játszik a női gazdasági függetlenülés a házasságoknak válással való befejezésében is: a házasságokat nem tartja többé össze az a kényszer, amely az egyik fél teljes kiszolgáltatottságából adódhat (Cseh-Szombathy 1995).

A kereszténység a házasságot, mint felbonthatatlan intézményt interpretálta. A házasság tartósságát a transzcendentális mondat garantálta: „Amit Isten összekötött, azt ember ne válassza szét." Jelenleg e transzcendentális biztosítéknak az értéke gyengül és szétfoszlik. Egyre kevésbé tartja vissza a házassági eskü, fogadalom a házasokat attól, hogy a házasságban felmerülő konfliktusaik megoldására a válást tekintsék eszköznek.

A legnagyobb változás abban látható, hogy „viszonylag csökken annak a meggyőződésnek az értéke és fontossága, hogy a házasság egyik célja a tartósság és hosszantartás” (SYNGLY 1999. 111.). Jelentős tényezővé vált az a növekvő tendencia, hogy a házasságot az egyéni elégedettség szempontjából ítéljük meg. Ezzel kapcsolatban Giddens (1999. 165.) úgy nyilatkozik, hogy „a növekvő válások száma nem jelenti feltétlenül a házassággal való mély elégedetlenséget, inkább a növekvő törekvést az értékes és jelentőségteljes kapcsolat elérésére”. A párkapcsolatok formálódásának szembetűnő tendenciája a házasságkötési kedv lanyhulása és a házasságon kívüli együttélés terjedése. A társadalom megítélése a házassággal kapcsolatban megváltozott. Úgy tünik, a házasság, mint a párkapcsolat preferált formája elvesztette kizárólagos fontosságát.

\section{Változások a demográfiai magatartásban}

A rendszerváltás utáni időszakban a partneri és demográfiai viselkedés Szlovákiában (a többi posztkommunista országban egyaránt) elkezdett jelentősen változni. Bútorová et al. (2008) hangsúlyozzák, hogy az 1989 előtti időszakban jellemző volt bizonyos egyöntetüség a demográfiai magatartásban: magas házasságkötési és viszonylag alacsony válási arány, a nők alacsony szülési életkora (Szlovákiában 22 év körül), alacsony házasságkötési életkor (Szlovákiában 21 év körül), a gyermekek több mint 90\% -a született házasságban, elterjedt a kétgyermekes családmodell. A szlovák társadalomban bekövetkezett átalakulási folyamatok, különböző gazdasági-társadalmi körülmények alakulása, a nyugati világtól való izoláltság megszűnése, a nyugati kultúra beáramlása stb. jelentős változásokat eredményezett a demográfiai magatartásban a 20. század 90-es évei közepén.

A továbbiakban kiemelünk néhány fontosabb, bekövetkezett változást:

Későbbi életkorra tolódott a gyermekvállalás. Ennek következtében a gyermeket vállalók jelentős része több élettapasztalattal rendelkezik, tudatosabbá válik a gyermeknevelés, a kötődés, a gondoskodás. 
Kevesebb gyermek születik, ám ahol van, ott felértékelődik. ScHNEIDER (2009) arra az általános trendre alapozza nézetét, mely szerint „ahol a gyermekek száma, valamint születésük időpontja racionális tervezés tárgyává válik, ott a szülővé válás motivációjaként egyre növekvő mértékben a gyermekek általi önmegvalósítás, a gyermek feletti öröm és a szülői szerep szubjektív felfogása lép előtérbe”. A folyamatosan csökkenő születések száma a népesség elöregedéséhez vezet, illetve a nukleáris családok és családháztartások létszámának csökkenéséhez. Növekszik a gyermektelen házaspárok aránya is, és ez csak részben magyarázható genetikai ártalmakkal. Egyre többen döntenek akaratlagosan úgy, hogy nem akarnak utódokat. A legújabb kutatási eredmények azt mutatják, hogy jelenleg terjedőben van a gyermek vállalását tudatosan elutasító szemlélet, az, amely a házasságkötés elkötelezettségéhez hasonló korlátozást lát a megszülető gyermekben és nem kívánja szabadságát feladni, s ezért nem akar gyermeket sem. A család egyik alapvető funkciója társadalmunkban az utódok létrehozása, mely biztosítja a társadalom népességének újratermelődését, ezért napjainkban a gyermekszám alakulása nem kevés gondot okoz a társadalomnak a népesség utánpótlása szempontjából.

Csökkent a kettő, és növekedett az egy, ill. a három- és többgyerekes családok aránya. Erősödött a polarizálódás, azonban ezen belül az egygyerekesek arányának a növekedése jóval jelentősebb.

Kevesebb gyermek él többgenerációs családban, csökken a nagyobb háztartások aránya. A közös háztartásban együtt élö, három vagy több nemzedék tagjaiból álló családok már csak töredékét képviselik a népességnek.

Gyorsan növekszik az egyszemélyes háztartások aránya. Tомка (2000. 51.) szerint ez egyrészt arra vezethető vissza, hogy a halálozási viszonyok javulása miatt emelkedett az idősek száma, akik dolgoztak, vagy a javuló jóléti szolgáltatások miatt egyre kevésbé voltak ráutalva rokonaikra, $s$ a leginkább talán individualizációként leírható értékváltás miatt is egyre többen éltek egyedül. Másrészt emelkedett az egyedül élő fiatalok száma, akik különösen a nagyvárosokban sajátos életformát, kultúrát kezdtek teremteni maguknak („Singles”). A korábbi történelmi időszakokkal szemben, amikor elsősorban a megözvegyült, gyerekeiket már felnevelt idősek éltek egyedül, ma az egyszemélyes háztartásokat hasonló arányban alkotják 40 éven aluliak. Miként UTASI (2004) és ToмášEK (2006) kutatási eredményei mutatják, a magányos életvitel nem mindig választás következménye. Az egyedülállók túlnyomó többsége saját szándékai szerint csupán elhalasztja a párválasztást, családalapítást - gyakran egzisztenciális bizonytalanság, néha a párkapcsolatok sorozatos meghiúsulása miatt - de nem akarna végleg lemondani róla. Az egyedülálló fiatalok többsége számára a házasságkötéshez vezető szociokulturális nyomás erösebb, mint az a motiváció, hogy egyedül maradjanak.

Egyre későbbi életkorban történik a házasságkötés, vagy akár el is marad. Lényegesen csökkent a törvényes házasságkötések száma (GÁвOR 2012). A kilencvenes évek derekától még a gyermek születése sem vezet feltétlenül a kapcsolat törvényesítéséhez. Növekszik azon gyermekek száma, akik élettársi kapcsolatban élő párok vagy egyedülálló anyák gyermekeik. Például Szlovákiában 1990-ben a gyermekek 7,6\%-a született házasságon kívül, 2012-ben már a gyermekek 35,4 \%-a (Bútorová et al. 2008). A házasságon kívüli születések emelkedő aránya összefügg a házasságon kívüli együttélések terjedésével, azaz ezek a születések is zömmel családban, ha nem is törvényesítettben, következnek be. A házasságkötés nélküli kapcsolatok ellátják azon funkciók zömét, amelyeket a hagyományos családok elláttak a XX. század első felében.

Fokozatosan emelkedett a válások száma, a törvényes házasságok instabilitása. Ebből adódóan gyakran gond az ilyen családok emocionális zártsága, támasznélkülivé válása. Ennek 
következtében egyre nagyobb az egyedülálló szülők aránya, az apák és gyermekeik térbeli elkülönülése, de a nem vér szerinti szülö (nevelőszülö) és a gyermek együttélésének terjedése is. Társadalmunkban óriási gond a válások számának tartósan magas száma. Ennek okai igen sokrétüek, a tolerancia hiánya, az érzelmi sivárság, a minimális együtt töltött idő, az alkohol stb. mind szerepet játszik.

$\mathrm{Az}$ együttélések mintája és formája egyre tarkább lett. A családi háztartások összetétele egyre vegyesebb képet mutat a válások, újraházasodások, adoptálások és egyéb események nyomán. VAJDA-KósA (2005. 168.) szerint „a néhány évtizeddel korábban általánossá vált parsonsi nukleáris családok aránya, amelyben a gyermek felnevelkedéséig vér szerinti apjával és anyjával élt, az össznépességen belül kisebbséggé változott. A második leggyakoribb családforma, az egyszülős család aránya ma a fejlett országokban a kétszülős, gyermekes házaspárok fele-harmada”. Az egyszülős családok száma a közelmúltban két okból is gyarapodott: egyre gyakoribb a válás, különélés, vagy azért, mert a megkötött házasság felbomlik, vagy azért, mert az össze sem házasodott pár külön költözik. Emellett egyre több nő stabil párkapcsolat nélkül szül gyermeket. TyDLITÁTOVÁ (2011) rámutat az egyedülálló szülők (akik döntő részben anyák) nem kedvezö helyzetére, mely szerint gyermekeik sokkal nagyobb arányban vannak kitéve a szegénység kockázatának, mint más családtípusokban. A jövedelemhiány a párkapcsolatok felbomlása után elsősorban abból származik, hogy a nők átlagos keresete eleve kisebb, s a gyermeket egyedül nevelő anyák munkaerő-piaci helyzete különösen kedvezőtlen. A modernizáció nyomán a legtöbb országban megfigyelhető tehát a családszervezet pluralizálódása, az individualizált életformák és alternatív együttélési formák terjedése (BECK 2016). HARCSA (2014) szerint valójában arról van szó, hogy az utóbbi évtizedekben a korábban kisebb számban jelenlevő, és nem, vagy csak kevésbé elfogadott családformációk váltak mindinkább tömegessé. Ezért inkább a különböző családformákkal kapcsolatos társadalmi megítélés pluralizálódásáról lehet beszélni.

\section{Változások a családi kapcsolatok terén}

Az utolsó évtizedekben az európai családokban végbement változások GuRáŇFilADELFIOVÁ-RiTOMSKÝ (1997) szerint a kővetkező folyamatokat eredményezték:

A családi kapcsolatok demokratizálódása - a hagyományos, patriarchális, a férfi tekintélyén és a gyermekek alárendeltségen alapuló kapcsolatok fokozatos átalakulása modern kapcsolatokra, melyek a nem és generáció szempontjából egyenlők.

A családi kapcsolatok individualizációja - az előre meghatározott, az ember eredetéből adott kapcsolatok fokozatos átalakulása nagyrészt választott, az egyén által szabadon alakított kapcsolatokra.

A családok dinamizálása - a család egyre nyitottabbá, egyre inkább képessé válik alkalmazkodni a társadalmi változásokhoz, ill. a család individuális életében bekövetkezett változásokhoz.

A családformák pluralizálódása - az előző folyamatok következménye, egyre szélesebb és bonyolultabb családi kapcsolatok és nagyobb számú családi (korábban kisebb számban jelenlevő) struktúrák kialakulása, melyek új, saját viselkedési minták alapján müködnek.

A jelenkori családok egyik jellemzője a változékonyabb szerepmegosztás. A munkavállalás elterjedésével, a növekvő szabadidővel és egyéb tényezőkkel párhuzamosan kezdtek a férjek több háztartási feladatot ellátni, az apák pedig több időt tölteni gyermekeikkel. Módosult tehát a háztartási teendők, jogok és kötelességek köre, a szerepek kölcsönös meghatározása, s változnak a házastársi kapcsolatok is.

Lényeges a kétkeresős családok dominánssá válása, mégpedig úgy, hogy egyre nő azon 
kétkeresős családok hányada, amelyben a feleség-élettárs is magasabb szakmai képesítéssel rendelkezik és kereső munkáját nemcsak jövedelemforrásnak tekinti, hanem karrier-ambíciói is vannak. A mai „kétkeresős családban” az apa hagyományosan értelmezett szerepe, hogy ő a "családfö”, mindinkább felülvizsgálatra szorul. A hagyományos apa-szerep, eltartani a családot, gondoskodni a megélhetésről stb. a gyakorlatban még megvan, de jelentős átalakulása már érezhető. A „korszerü” apa ma már segíti, támogatja, fejleszti gyermeke személyiségét, és ezt az anyával együtt, egyenrangú partnerként teszi. „A modern család legfontosabb jellemzője az egalitáriánusság, az egyenlőségen alapuló, demokratikus nyitottság, melyben a döntéshozatal, a családi feladatok megoldása, a gyermek gondozása, nevelése stb. az egyenlőségen, szimmetrián alapul" (VARgA 1997).

A házas nők zöme is keresőmunkát végez. Ezt legjobban az a modell fejezi ki, amely a múltban a házastársak közötti aszimmetrikus szerepmegosztást emeli ki, s ezzel szemben ma a szimmetrikus megosztást tekinti jellemzőnek. СseH-Szombathy (1995. 143.) szerint „ez a szimmetria inkább csak cél, ideál, de a felé való előrehaladás kétségtelen”. Ez azt jelenti, hogy a családok fenntartásához szükséges javak előteremtéséhez, a családi jövedelem megszerzéséhez a feleségek mindinkább a férjükhöz közelítő arányban járulnak hozzá, viszont az otthoni feladatokba, elsősorban a gyerekek ellátásába, egyre eröteljesebben kapcsolódnak be a férjek.

Az utóbbi évtizedekben az anyai szereppel ellentétben, az apai szerep jelentősebben változott. Az apák megszabadultak a hagyományos apai szereptől, egyre több feladatot látnak el a háztartásban, és több időt töltenek gyermekeikkel. MAтĚJČEK (1986. 58.) alítása szerint „a jelenkori apa feladatai a családon belüli életre irányulnak. A jelenkori apának nincsen annyi feladata ez anyagi javak biztosításával, de annál igényesebb feladatok hárulnak rá a harmonikus családi lékkör biztosításával kapcsolatban”.

A nemek közötti szereposztás közelített egymáshoz, mind szélesebb körü az elvárás, hogy a férfiak vegyenek részt az otthoni munkában és a gyermeknevelésben. Az apák gyerekük nevelésében való részvétele szelekciós. Főleg olyan feladatokat vállalnak, melyek emocionálisan gazdagítják őket és megfelelnek szükségleteiknek, elvárásaiknak (pld. sport, kirándulás, játék). A női munkavállalás elterjedésével a mai apák többet vannak együtt gyerekeikkel, inkább vesznek részt életükben, mint a korábbi nemzedék férfitagjai. Kutatási eredmények alapján megállapítható, hogy az utóbbi fél évszázadban egyértelműen és tendenciaszerüen nő az apák részvétele gyermekük gondozásában, ill. nevelésében. A 80-as évekből származó kutatási eredmények alapján megállapítható, hogy nő az olyan apák száma, akik részt vesznek gyermekük gondozásában, kiváltképp az óvodás korban (LEwis et al. 1981).

A fenti adatok imponálóan illusztrálják a növekvő apai részvételt a gyermekkel kapcsolatos szülői feladatkörökben, bár a nemek terhei messze nem egyenlők ma sem a gyereknevelés és gondozás terén. Holubová (2011) és Harcsa (2014) kutatásai alapján megállapítható, hogy az apák a gyermekekkel való szabadidős tevékenységeknél játszanak meghatározóbb szerepet. A háztartás mindennapi ellátása, valamint a gyermek gondozása, nevelése továbbra is az anyák felelőssége. Az anyák domináns szerepe a közvetlen gyermekgondozási tevékenységeknél kimutatható abban az esetben is, ha az anyák munkaviszonyban vannak (CHALOUPKová 2005). $\mathrm{Az}$ apák gyermekgondozásában, valamint otthoni munkában való részvétele továbbra is lényegesen alacsonyabb, mint az anyáké. MAříková (2006) vizsgálataiból kitűnik, hogy elsősorban az anyák hatáskörébe tartoznak a gyermekgondozással kapcsolatos rendszeres (mindennapi kommunikáció, alapvető gondoskodás) és időigényes tevékenységek (betegápolás, tanulás). Az apa az anyával együtt olyan tevékenységekben vesz részt, ahol nem szükséges a rendszeresség (például: a továbbképzés kiválasztása, ajándékok vásárlása). 
Átalakultak a szülők és a gyerekek közötti kapcsolati mintázatok is. A szülők és gyermekek kapcsolatának alakulása a hosszabb távú, több évtizedes tendenciákat követi. Ezek közül ki kell emelni a tekintélyelvű nevelési normák gyengülését és a megengedő nevelés gyakorlatának erősödését a családokban. A mai szülők körében elterjedt az elnéző, engedékeny nevelői magatartás. Okául az idő és energia hiányát szokták felhozni legtöbbször. Ennek megfelelően változnak a jutalmazás és büntetés családi (és iskolai) módszerei, s ez a változás együtt jár a gyermekek jogainak és önállóságának előtérbe kerülésével. A gyerekek szabadabbak, de magukra hagyottak (GÁBOR 2012; JANCSÁк 2013). Emellett, a televíziózás, az internet és a modern tömegkultúra más eszközeinek elterjedésével, használatának fokozódásával a szülők egyre kevésbé tudják ellenőrizni azt, hogy a gyerekek mit tudnak meg a felnőtt világról (JANCSÁK 2013; KARIKó 2016).

A mai szülők a korábbi generációkhoz képest kevésbé idegenkednek attól, hogy együtt játszanak gyerekükkel, együtt töltsék a hétvégét és a szünidőt, együtt utazzanak. Az amerikai és más nemzetközi adatok is azt jelzik, hogy az utóbbi 2-4 évtizedben jelentősen növekedett a foglalkoztatott anyáknak és apáknak a gyermekek gondozásával és nevelésével kapcsolatos időráfordítása (HARCSA 2014). A nemzetközi kutatások rámutatnak az együttlét minőségének a fontosságára: aszerint a gyermekek jobban méltányolják az együtt töltött idő minőségét, mint annak mennyiségét (TuRTIANEN - KaRVONEN - RAHKonen 2007).

Az utóbbi évtizedekben meghosszabbodott a gyerekkor és ifúkor, megnőtt az az időszak, amit a felnövekvő nemzedék tagjai szüleikkel együtt, azok családjában és háztartásában töltenek el. A fiatal felnőttek később hagyják el a szülői házat (Somlai 1997; VAsKovics 2014; BúToRová et al. 2008). Szlovákiában (és Magyarországon) is megfigyelhetök azok a jelenségek, amelyek a post-adolescence-korral járnak, mint például a felsőfokú tanulmányok elhúzódása, a házasodási és pályaválasztási döntések, ill. a gyerekvállalás késleltetése.

\section{A család átalakulásának okai}

Több tanulmány, kiadvány kísérelte meg a válaszadást arra a kérdésre, hogy mi a fent vázolt változások oka, miként értékelendők e jelenségek és hogy miként lehetne (amennyiben ez lehetséges) megváltoztatni a tendenciákat. A modern családokban tapasztalható életvitel egyre többféle változatának lehetünk tanúi. Az okok összetettek, sokfélék:

A rendszerváltás, a globalizáció és más tendenciák hatásara egyidejüleg bekövetkezett egyéni szabadság tágulása és a különféle kényszerek erősödése, különféle vállalkozási, kommunikációs és mobilitási lehetőségek kiszélesedése, a megélhetési, tanulási és egyéb kényszerek ereje (Somlai-Tóth 2002).

A megváltozott szexuális erkölcs, a női munkavállalás, médiák (VAJDA-KósA 2005).

A rendszerváltás okozta gazdasági nehézségek, a hirtelen megnőtt aspirációk, a felsőoktatás expanziója és a régió nyitottabbá válása, a nyugati értékek és életformák átvételének igénye (Tомка 2009).

A képzés időtartamának növekedése, a későbbi munkavállalás, a megnövekedett igények, az anyasághoz és apasághoz kötődő magas elvárások, a megváltozott fogamzásgátló lehetőségek (VAsKovics 2014).

A következőkben felülvizsgálunk néhány társadalmi jellegü tényezőt, melyekről úgy véljük, hogy nagymértékben kiváltották, ill. determinálták a korszerü család transzformációs trendjeit a modern társadalomban. A téma alaposabb elemzése megvilágítja, hogy összetett problémáról van szó, amely a posztmodern gazdaság és társadalom müködésének integráns része. 
A család szerepének átalakulásában fontos körülmény, hogy az egyén társadalmi integrációjának lehetőségei egyre inkább a családon kívülre helyeződnek, elsősorban a fogyasztás, a gazdasági szervezetekben és az elektronikus kommunikációban való részvétel közvetítésével valósulnak meg. A modern társadalom megszabadította az egyéneket a szélesebb családhoz, közösséghez, az egyházhoz való kötődéstől (MAтоušEk 1997). CseH-Szombathy (1995) ezt azzal magyarázza, hogy a gazdálkodásra ható változások együttesen lazábbá tették a családtagokat összefogó kötelékeket, gyengítették a családhoz tartozás motivációját, és értelmetlenné tettek számos olyan családi hagyományt, amelyet korábban az együvé tartozás érzésének fennmaradásában szerepet játszottak.

A család átalakulásának folyamataiban fontos szerepet játszó körülmény az értékek és normák szerepe. Egyrészt a normák pluralizálódása és a kulturális horizontok tágulása (SoMLAI 1997), valamint az anómia, a normák hiánya, amely nehezíti a fontos döntéseket, az összekerülő párok életcéljainak, értékeinek összeegyeztetését (VAJDA-KósA 2005). A normák meggyengülésének egyik oka a definiálható közösségek megszünése: a normák, még a legelvontabb értéken alapulók is, csak akkor müködnek, ha egy meghatározott közösség vagy annak mértékadó tagjai elfogadják öket. A globalizációs folyamatok nemcsak a nemzeti identitást, hanem más csoportosulások, köztük a családi közösség müködését is veszélyeztetik. Az utóbbi évtizedek kutatásai a nyugati országokban arra utalnak, hogy a hagyományos családi normáknak a hatása erősen meggyengült, s olyan új normák terjedtek el, amelyek összhangban vannak a megváltozott családi magatartásokkal és az individualizáció irányába mutatnak. Megfigyelhető, hogy a fiatal és középkorú felnőtt népességben terjedőben van - de még csak egy kisebbségre jellemző - a tradíciókkal való szembefordulás. A tradicionális normák helyett előnyben részesíti a spontaneitást, a kísérletezést, az új élmények keresését, illetve az egyéni, privát szféra megőrzését még a házastárssal szemben is.

Egy másik ok a szexuális erkölcs változása. Dannecker (2003) szerint a hagyományos szexuális erkölcs, amely egy bizonyos szexuális magatartásból indul ki, elveszti törvényességét. A jelenkori szexuális erkölcs központi kategóriája az elfogadott, jóváhagyott szexuális viselkedés követelménye. Ezt azt jelenti, hogy azt hogy milyen a helyes, illetve helytelen viselkedés, nem a külső tekintélyek döntik el, hanem maguk a résztvevők.

A megváltozott társadalmi keretfeltételek egyik legfontosabb tényezője a „gyermekjólét” értékének kulturális legitimálása, amely időbeni eltérésekkel ugyan, de általánosan megfigyelhető jelenség. A gyermek magas szubjektív „értéke”, valamint az életút tervezésénél a „gyermekjólét" növekvő társadalmi elvárása az elmúlt évtizedekben megváltoztatta a szülőiséghez kötött individuális elvárásokat (VAsKovics 2014). Hasonlóképpen nyilatkoznak ONDREJKOVIČMAJERČí́KovÁ (2006), akik szerint mindez összefügg az elterjedt „felelősségteljes szülőiség” idealizált eszményképpel. A szülőiség intézménye a szülők egyre igényesebb nevelési elvárásaival és a szülői kötelezettségtudattal jár együtt. Növekednek a szülöiséggel kapcsolatos elvárások. Mindkét szülő foglalkoztatása, a szabadidővel, a gyermekgondozással, neveléssel szembeni követelmények növekedése, a családtagok családon kívüli kötelezettségei, a munkahely távolsága a lakóhelytől, a konszenzus keresése, ezek a mindennapi életet olyan jelenségei, melyek rendkívüli igényeket támasztanak a család minden tagjával szemben.

CseH-Szombathy (1990) véleménye szerint mélyebb életfilozófiai problémáról van szó. Arról nevezetesen, hogy mennyiben kiszámítható, mennyiben megtervezhető az élet és vállalhatja-e az ember a gyermekkel járó felelősséget magára, akkor, amikor annyi minden bizonytalan, többek között saját nézeteinek, vágyainak, céljainak jövendő alakulása is. E bizonytalanság közepette 
a spontaneitás, a pillanatnyi lehetőségek kihasználása kerül előtérbe, ami ütközik a hosszabb távra szóló kötelezettségek vállalásával. Így alakul ki az a magatartás, amely nemcsak korlátozni kívánja a születendő gyermekek számát, hanem egyáltalán nem akar gyermeket.

Számos vizsgálat tapasztalatai azt mutatják, hogy a mai társadalomban az egyetemes értékek jobbára elvesztették érvényességüket, és helyükre az aktuális helyzetnek megfelelö - alapvetően érdekorientált - cselekvések kerültek (GIRÁN-LigETi 2000). Hasonlóképpen nyilatkozik BREZINKA (1996), aki szerint az értékek változása a kötelességek és akceptáció értékekeitől az önfejlesztő egocentrista értékek felé halad.

$\mathrm{Az}$ anómia sokféle oka között fontos helyen szerepel a munka-és gazdasági körülmények folyamatos változása, az országok és országrészek közötti vándorlás, a munkavállalás változó feltételei vagy éppenséggel a munkalehetőség hiánya, amely lehetetlenné teszi a tartós családi identitást. SCHNEIDER (2009) szerint megállapítható, hogy a hagyományos, tartós és egy konkrét helyhez kötött foglalkoztatási viszonyokat fokozatosan felváltják azok a tevékenységek, amelyek színhelye változó, és amelyek gyakoribb hivatás- és munkaadóváltással és a foglalkoztatási helyek cseréjével járnak. A foglalkozási mobilitás ma már a korábbinál inkább cirkuláris, míg a lakóhely szerinti mobilitás mértéke Európán belül csekély. Az emberek egyre inkább az olyan cirkuláris mobilitási formák, mint a napi vagy heti ingázás mellet döntenek. A cirkuláris mobilitás növekedése fokozódik, sokan az ingázást választják, mint stratégiát azért, hogy a költözést elkerüljék, és hogy a családi életet mindkét partner hivatásának gyakorlásával összhangba hozzák. A cirkuláris mobilitás az otthontól való hosszabb távolléttel jár együtt. Ezért egyre nagyobb számú férfi és nő feladata az, hogy a mobilitás miatti távollétet az egyéni stabilitás, közelség, intimitás szükségleteivel összekösse. Sok mobil pár szenved attól a problémától, hogy valamely közös színteret kell életük számára teremteniük. Ez a színtér a múltban egészen magától érthetően a család volt. A térbeli és időbeli együttlét a család számára alapvető volt.

Ma a családot sokszorosan jellemzi a családtagok életszféráinak széttörése. Annak megteremtése, ami egykor normális volt, ma gyakran alig megoldható feladat. Ahhoz, hogy a családtagok közösen töltsék az időt, komoly ráfordítás szükséges, melynek során a magánéletet a hivatali érdekekhez kell igazítani. Ahol ez nem sikerül, gyakran csak a nem kívánt alternatíva marad: hivatás vagy család. BECK (1994) a piac és a család közti ellenmondást emeli ki. Magyarázatul azt vallja, hogy a modern társadalom a rugalmas munkaerő mobilitását követeli meg függetlenül a dolgozók személyes helyzetétől és ilyen környezetben az ideális munkaerő a szabad, kapcsolatoktól, házasságtól, családtól független egyén.

A változások különösen jelentős okának lehet tekinteni a „nőies életmód”-ban bekövetkezett változásokat. Miután a nők nagy tömegei bekapcsolódtak a termelőmunkába, tarthatatlanná vált a hagyományos családi szerepük. A 20. században, főként annak második felében a nők egyre inkább bekapcsolódtak a szakoktatásba, majd a felsőoktatásba, és ezzel párhuzamosan kiszélesedett a női munkavállalás köre. További fontos változás, ahogy megjegyezte CsEH-SzombATHY (1995), hogy míg a kezdetben a nők zöme szaktudás nélkül került munkahelyére, most nagyobb hányaduk rendelkezik képesítéssel. Ez a családi élet szempontjából azzal a következménnyel jár, hogy a karrier-elképzelés a nők számára is jellemző: ők is úgy képzelik el életük alakulását, hogy a tanultakat hasznosítsák, és ezen a téren sikereket érjenek el.

A nők magas foglalkoztatási aránya okozza pld. a csökkenő gyermekvállalási tendenciát. Akkor, amikor a keresőmunka végzését, egy foglalkozási pálya folytatását a gyerek születése szükségszerüen meg kell hogy szakítsa, és a kisgyermekek a továbbiakban is korlátozzák a szülök, elsősorban az anya munkavállalásait, akkor magától értetődő, hogy az asszonyok meg- 
gondolják, hogy hány gyermek megszületésére is vállalkoznak. A nők magasabb szintű iskolai végzettségének, hivatásra felkészítő szakmai képesítésének szükségszerü következménye, hogy megváltoztak igényeik a tartós partneri kapcsolatok tekintetében, más alku-pozíciójuk van a férfiakkal szemben, mint amilyen nagyanyáiknak, de még anyáiknak is volt, és másként értelmezik a gyermekszülést és a gyermekkel járó feladatokat is. Míg a múltban a család és az anyaság a nők számara sors jelentőségü volt, ma választási lehetőséget jelent. MožNÝ (1990.121.) szerint „a hagyományos társadalomban a házimunka a nőt egy magasabb rendü társadalmi rendszerbe integrálta, a jelenkori nők számara a háztartás a szociális izoláltság helyévé változott”.

Túlzott leegyszerüsítés volna a család szerkezetében és müködésében bekövetkezett változásokat csupán a nők foglalkoztatása terén lezajlott és még ma is folyó átalakulással magyarázni, de kétségtelen, hogy ez kiemelt jelentőségű, mind a házasságkötés nélküli együttélések terjedése, mind a válások arányának növekedése, mind pedig a termékenység csökkenése szempontjából.

Manapság gyakran tapasztalhatjuk, hogy a partneri kapcsolatokban jelen van az egyéni szabadság maximális biztosítása. A családon belüli kapcsolatokat tehát a posztmodern ideológia mellett az egyéni szabadság minél erőteljesebb megőrzése, és az egymástól való függetlenség jellemzi. Ahogy MatoušEk (1997. 31.) nyilatkozik, „jelenkorban már nem a gyermekek miatt alakult ki családokról beszélünk. Ma olyan családokról van szó, ahol első helyen a felnőtt családtagok egyéni érdekeik vannak”. A korábbi időkhöz képest magasabbak lettek az elvárások, hogy a kapcsolat személyesen kielégítö legyen.

ONDREJKOVIČ (2002) az individualizáció következményei közül kiemeli a hagyományos normák és értékek kötelező erejének gyengülését, illetve az erkölcsi és vallási törvények jelentőségének csökkenését. Ez szorosan összefügg a városokban jelenlevő anonimitással, a szociális ellenőrzés csökkenésével, az új függőségek kialakulásával (a munkapiactól, az egészségügyi biztosítástól, a képzési rendszertől stb.). Az egyén individuális lehetőségei ugyan tágulnak, de a személyes kockázat és bizonytalanság úgyszintén.

Az együttélési formák változatossága csak részben tulajdonítható az egyéni szabadság növekedésének, a bővülő választási lehetőségeknek (női munkavállalási lehetőségek, gyermekintézmények). A kialakuló helyzet gyakran nyilvánvaló kényszer, és nem választás következménye: az egyedülálló szülők, anyák csak egy töredéke képzelte el eleve így az életét, mint ahogyan a gyermeket vállaló férfiak közül sem sokan tervezik el, hogy csupán „láthatáson” találkoznak a gyermekükkel.

\section{Befejezés}

A rendszerváltással elindult társadalmi, gazdasági és politikai változások nem hagyták érintetlenül a családot, mint társadalmi intézményt sem. Nemcsak az egyének élete változott meg jelentősen, hanem a családok létszáma, összetétele és szervezete, működése és jelentősége is. Ezeknek a változásoknak egy része már korábban kezdődött, $\mathrm{s}$ a jelenlegi állapot az akkor, esetenként évtizedekkel előbb elindult folyamatok felerősödésének eredménye. A fejlett országok demográfiai jelzőszámai már hosszabb ideje a termékenység csökkenéséről, a házasságkötési szándékok lanyhulásáról, a válások számának növekedéséről, az élettársi kapcsolat, mint életforma terjedéséröl tudósítanak. E folyamatok - bár némi késéssel - egyre inkább érzékelhetők hazánkban is.

A gyerekek mikrokörnyezetében egyre nagyobbak az eltérések és rendezetlenségek, szé- 
lesedő skálán mozog a születések ütemezése, egyre kevesebben élnek egész gyermekkorukban vér szerinti apjukkal és anyjukkal. A jelenlegi családok válságjelenségei közül ki kell emelnünk az alábbiakat: a házasodási hajlandóság és a gyermekvállalási kedv csökkenését, a válások magas arányát, az egyszülős családok gazdasági és szociális problémáit, a szingli életforma és a házasságkötés nélküli együttélési formák terjedését. A modern társadalmak családjai sokkal kiszolgáltatottabbak globális gazdasági, politikai, katonai és kulturális erőknek, mint öseik, a hagyományos társadalmak tagjai és családjai voltak.

A fent vázolt transzformációs folyamatok gyakran vitát indítanak a család válságáról, nemcsak nálunk, hanem Európa szerte egyaránt. A nyilvános és szakmai diskurzus azon kérdések megválaszolására irányul, hogy milyen hatással vannak a családra a gazdasági és politikai társadalom alapjaiban bekövetkezett globális változások, milyen hatásuk van a családban beállt változásoknak a gazdasági jövőre és a társadalmi jólétre. Abból a feltételből indul ki, hogy nemcsak a családoknak kell módosulniuk, hogy alkalmazkodjanak a valósághoz, de a kulturális normáknak, közpolitikai és jogi rendszernek, intézményeknek is alkalmazkodniuk kell az új családi mintákhoz.

Legfontosabb feladatunk az új családi értékek kialakulása, a tradicionálisan jó értékek átmentése, ápolása. Ezek az értékek, amelyeknek lehet erkölcsi, esztétikai, intellektuális és magatartásbeli tartalma a családi életre való felkészítés részének kell hogy váljanak.

\section{IRODALOM}

BECK, UlRiCH (1994): Riziková společnost. Praha, Slon.

BECK, UlRich (2016): Távszerelem / Távszeretet. Szeged, Belvedere Meridionale.

Brezinka, Wolfgang (1996): Filozofické základy výchovy. Praha, Zvon.

Bútorové, Zora et al. (2008): Ona a On na Slovensku, zaostrené na rod a vek. Bratislava, Inštitút pre verejné otázky.

Cseh-Szombathy László (1990): Családi viszonyok. In. Andorka Rudolf et al. (Eds.): Társadalmi riport. Budapest, Tárki. 487-500.

Cseh-Szombathy LÁszLó (1995): A családiértékek változása és ennek hatása a családi funkciók alakulásásra. In. Bakácsiné Gulyás Mária (Ed.): A nevelés társadalmi alapjai. Szeged, JGYTF kiadó. 141-153.

Dannecker, Martin (2003): Sexualität im Wandel. AIDS Infothek: Das Magazin der Aids info Docu Schwiez, 15. 10-19.

De Syngly, François (1999): Sociologie současné rodiny. Praha, Portál.

Doмbi Alice (2010): A kisgyermekkori élmények hatása a gyermek fejlödésére. In Dombi, A. - Soos, K. (eds.): Fejezetek a kisgyermeknevelés köréből. Gyula, APC stúdió. 82-83.

Dомві Mária (2012): Az én gyerekem más. A szociálpedagógus szerepe a szülői elfogadás, segítségnyújtás támogatásában problémás gyerekek esetében. In Dombi, A. - Dombi, M. (eds.): Fejezetek a szociálpedagógia köréböl. Szeged, Universitas Kiadó. 117-125.

GÁBor, Kálmán (2012): Válogatott ifjúságszociológiai tanulmányok. Szeged, Belvedere Meridionale. Giddens, Anthony (1999): Sociologie. Praha, Argo.

Girán János - Ligeti György (2000): Szociológiai alapismeretek. Pécs, Comenius.

Guráň, Peter - Filadelfiová, Jarmila - Ritomský, Alojz (1997): Tradičné verzus moderné: zmeny a život súčasných rodín. Sociológia - Slovak Sociological Rewiew vol. 29. no. 1. 5-20.

HaRCSA István (2014): A családi kohézió trendjei a gyermekes családokban. Szociológiai szemle 24. évf. 1. sz. 40-66.

HolubovÁ, BARBORA (2011): Súhrnná správa o stave rodovej rovnosti na Slovensku rok 2010. Bratislava: Inštitút pre výskum práce a rodiny. 
JANCSÁK, CsABA (2013): Ifjúsági korosztályok korszakváltásban. Budapest, Új Mandátum Könyvkiadó. Chaloupková, Jana (2005): Faktory ovlivňující dělbu domácí práce $v$ českých domácnostech a hodnocení její spravedlnosti. Sociologický časopis/Czech Sociological Review, 41, 1, 57-77.

KARIKó, SÁNDOR (szerk.) (2016): Ifjúság a globális térben. Szeged, Szegedi Egyetemi Kiadó.

Lewis, Michael et al. (1981): The father as a member of the child'social network. In Lamb Michael.E (Ed.): The role of father in child development. New York, John Wiley. 259-294.

Maǩíková, Hana (2006): Muži mezi rodinou a prací. In. Ondrejkovič Peter (Ed): Rodina v novom miléniu. Nitra, UKF. 81-88.

MATĚJČĚK, ZDENĚK (1986): Rodičě a děti. Praha: Avicenum.

MATOUŠEK, OLDŘICH (1997): Rodina jako instituce a vztahová sit. Praha, Slon.

MožNÝ, Ivo (1990): Moderní rodina - mýty a skutečnosti. Brno, Blok.

MožNÝ, Ivo (2006): Rodina a společnost. Praha, Slon.

ONdRejKovič, Peter (2002): Globalizácia a individualizácia mládeže. Negatívne stránky. Bratislava, Veda.

ONDREJKOVIČ, PETER - MajeRČíková, JANA (2006): Zmeny v spoločnosti a zmeny v rodine. In. Ondrejkovič Peter (Ed): Rodina v novom miléniu. Nitra, UKF. 29-43.

Plaňava, Ivo (2000): Manželství a rodiny. Brno, Doplněk.

RABušic, LADIsLav (2001): Kde ty všechny děti jsou? Praha, SLON.

SCHNeider Norbert (2009): Az Európai családok sokfélesége. Demográfia 52. évf. 4. sz. 267-282.

SOMLAi PÉTER (1997): Szocializáció. A kulturális átörökités és a társadalmi beilleszkedés folyamata. Budapest, Corvina.

Somlai PÉTER - TóTh OlgA (2002): A házasság és család változásai az ezredforduló Magyarországán. Educatio 11. évf. 3. sz. 339-348.

SOMlai, PÉTER (2013): Család 2.0. Együttélési formák a polgári családtól a jelenkorig. Budapest, Napvilág Kiadó.

TOMÁšEK, MARCEL (2006): Singles a jejich vztahy; kvalitativní pohled na nesezdané a nekohabitující jednotlivce v České Republice. Sociologický časopis vol. 42. no. 1. 81-105.

Tомка BÉLA (2000): Családfejlődés a 20. századi Magyarországon és Nyugat-Európában. Budapest, Osiris.

ToMka BéLA (2009): Európa társadalomtörténete a 20. században. Budapest, Osiris.

Turtianen, Pirjo - Karvonen, Sakari - Rahkonen, Ossi (2007): All in the Family? The structure and Meaning of Family Life among Yonung People. Journal of Youth Studies vol. 10. no. 4. 477-493.

Tyduttátová, Gabriela (2011): Pluralizácia rodinných foriem na Slovensku ako predmet demografickej analýzy v regionálnej optike. Sociológia vol. 43. no. 1.28-56.

UtAsi Ágnes (2004): Feláldozott kapcsolatok. Budapest, MTA Politikai Tudományok Intézete.

Vajda Zsuzsanna - Kósa Éva (2005): Neveléslélektan. Budapest, Osiris.

VASKovics LÁszló (2014): Családszerkezeti átalakulások európai kitekintésben. Szociológiai szemle 24. évf. 1. sz. 5-39.

VARGA István (1997:) Családi szocializáció és a korszerű család. In Gácser József (szerk.): Pedagógiai antológia IV. Szeged: JGYTF Kiadó. 265-292. 